\title{
ZFPM2/RUNX1 Fusion Gene
}

National Cancer Institute

\section{Source}

National Cancer Institute. ZFPM2/RUNX1 Fusion Gene. NCI Thesaurus. Code C99680.

A fusion gene that results from a chromosomal translocation $t(8 ; 21)(q 23 ; q 22)$ which fuses the first 6 exons of the ZFPM2 gene to exon 6 of the RUNX1 gene. This rearrangement is associated with one case of refractory anemia with excess blasts. 